\title{
ОСОБЛИВОСТІ ДЕРЖАВНО-ПРИВАТНОГО ПАРТНЕРСТВА В МЕДИЧНІЙ СФЕРІ В УМОВАХ ЗАБЕЗПЕЧЕННЯ СТАЛОГО РОЗВИТКУ
}

\begin{abstract}
Мета. Поглиблення теоретико-методичних аспектів формування та розвитку державно-приватного партнерства у сфері охорони здоров'я Украӥни в умовах забезпечення сталого розвитку.

Методика. На основі гносеологічного аналізу $i$ синтезу розкрито сутність $i$ зміст державно-приватного партнерства в медичній сфері та сформовано його авторську інтерпретацію; систематизація $i$ узагальнення застосовувались для визначення класифікаційних ознак державно-приватного партнерства та його галузевої специфіки.

Результати. У статті узагальнено наукову дискусію щодо застосування державно-приватного партнерства в сфері охорони здоров'я та зроблено висновок щзодо його актуальності як інструменту сталого розвитку крайни, регіонів $i$ окремих галузей. Визначено структурні елементи державно-приватного партнерства. На основі систематизації літературних джерел щодо підходів до визначення державно-приватного партнерства з'ясовано, щзо зміст категорії «держсавно-приватне партнерство» розкривається через взаємодоповнення проектного та інституційного підходів, а також в аспектах стратегічного розвитку та стилістичного прийому у широкому сенсі, в результаті чого надано авторське тлумачення категорії державно-приватне партнерство в медичній сфері. Систематизовано види державноприватного партнерства як інструменту сталого розвитку краӥни та ї̈ регіонів та обтрунтовано доиільність інтегрування різних проектів. Виявлено основні ознаки державно-приватного партнерства в медичній сфері, які розкривають специфіку партнерської взаємодії держави та приватного сектору як економічної категорії.

Наукова новизна. Удосконалення державно-приватного партнерства в медичній сфері як економічної категорії та систематизація його видів в аспекті сталого розвитку країни та ї̈ регіонів.

Практична значимість. Практичне значення полягає у визначенні специфічних рис державно-приватного партнерства у медичній сфері, щз можуть бути покладені в основу розроблення методичного забезпечення удосконалення системи охорони здоров'я Украӥни.
\end{abstract}

Ключові слова: державно-приватне партнерство, приватний сектор, медична сфера, охорона здоров'я, сталий розвиток.

Вступ. Останнім часом, не дивлячись на досить складні політичні обставини й не стабільну економічну ситуацію, держава впроваджує заходи щодо удосконалення управління життєво важливою галуззю соціальної сфери, як сфера охорони здоров'я. Це вимушена діяльність, адже вітчизняна сфера охорони здоров'я характеризується зниженою якістю та досяжністю допомоги населенню, недостатнім фінансуванням, неефективністю використання ресурсів, незбалансованістю структури медичної допомоги. Усе вище наведе потребує пошуку ефективних інструментів вирішення проблеми недосконалості системи охорони здоров'я 3 огляду на сучасні цільові орієнтири сталого розвитку в межах євроінтеграції України.

На думку автора, з проблем, що існують у сфері охорони здоров'я, перш за все, слід приділити увагу недостатності коштів i необгрунтованому та нераціональному освоєнні ресурсів. 3 цього приводу, актуальності набуває державно-приватне партнерство в якості інструменту державного впливу для вирішення головного протиріччя у сфері сучасної вітчизняної медицини - між економічними інтересами головних учасників, тобто пацієнтами (фактично усього населення країни), та медичними закладами, що має не тільки теоретичний, але й практичний сенс.

Аналіз останніх досліджень i публікацій. Серед вагомих наукових напрацювань щодо державно-приватного партнерства в медичній сфері слід назвати таких зарубіжних вчених, як М. Голдман [1], Д. Форджіа [2], Р. Кларк [3], Е. Ченг [4], що розкривають значущість i особливості організації відносин між державним i приватним секторами для покращення системи надання медичних послуг населенню. Сучасні вітчизняні наукові праці формують уявлення про форми реалізації проектів державноприватного партнерства у сфері охорони здоров'я [5], визначають його переваги i недоліки [6], перспективи в національному i регіональному розвитку [7, 8], подають пропозиції 3 удосконалення системи управління ризиками державно-приватного партнерства [9]. Водночас, 3 огляду на актуалізацію цільових орієнтирів України 
щодо сталого розвитку, який передбачає збалансованість усіх соціально-економічних потреб i можливостей, слід поглибити дослідження специфіки державно-приватного партнерства у сфері охорони здоров'я з метою його удосконалення задля вирішення проблем якості і доступності медичних послуг поруч із недостатнім фінансовим забезпеченням досліджуваної сфери.

Метою статті $\epsilon$ поглиблення теоретикометодичних аспектів формування та розвитку державно-приватного партнерства у сфері охорони здоров'я України в умовах забезпечення сталого розвитку. Для досягнення мети необхідно вирішити такі завдання:

- надати сучасну інтерпретацію
терміну «державно-приватне
партнерство»;
- удосконалити теоретико-методичну
базу державно-приватного
партнерства у напрямку розвнення
підходів до формуванні сталих
економічних відносин;
- систематизувати види державно-
приватного партнерства на різних
рівнях господарювання;
розкрити специфіку державно-
приватного партнерства у медичній
сфері.

Методи дослідження. Основними методами дослідження стали гносеологічний аналіз i синтез, на основі чого розкрито сутність i зміст державно-приватного партнерства як інструменту залучення приватних інвестицій в медичну сферу та сформовано авторську інтерпретацію досліджуваної категорії, а також систематизація i узагальнення, що застосовувались для визначення класифікаційних ознак державно-приватного партнерства та його галузевої специфіки.

Виклад основного матеріалу. Сучасна українська економіка націлена на модернізацію, сталий шлях розвитку, пошук нових центрів економічного зростання в регіонах, нове державне управління. У найближчі роки однією 3 відповідей України на сучасні виклики повинна стати динамічна економічна модель, здатна забезпечувати високий рівень життя громадян в регіонах країни. Одним 3 інструментів реалізації проектного підходу в державному управлінні, підвищення фінансового, технологічного, інноваційного потенціалу різних галузей економіки країни, соціально-економічного розвитку регіонів $\epsilon$ державно-приватне партнерство. В даний час за кордоном i в Україні проекти державно-приватного партнерства не тільки успішно реалізуються в різних сферах життя, що традиційно належали державі, але й використовуються як інструмент стратегічного розвитку економіки, регіональної політики, в тому числі інноваційної.

Державно-приватне партнерство сучасний інструмент розвитку економіки. Публічний сектор, що виконує свою економічну функцію, має можливість залучати приватний сектор для вирішення суспільно значущих і соціально важливих завдань. В умовах сталого розвитку спостерігається значний дефіцит бюджетних коштів для управління неспроможністю ринку медичних послуг. Державно-приватне партнерство $\epsilon$ дієвим інструментом залучення приватних інвестицій для виконання завдань публічного сектору.

Актуальним завданням сучасної економічної теорії $\epsilon$ вивчення умов щодо підвищення ефективності управління державно-приватним партнерством. Для вирішення цього завдання у дослідженні автором було проаналізовано теоретичні підходи до формування державно-приватного партнерства та виявлено різні їх переваги у партнерстві в системі охорони здоров'я.

В Україні поняття державноприватного партнерства почало активно впроваджуватися останні 10-15 років, тобто 3 початку XXI сторіччя в сучасній літературі відомо кілька понять державно-приватного партнерства. Різні автори зробили свій внесок у визначення державно-приватного партнерства, спираючись на різні аспекти поняття.

Так, у визначеннях державно-приватне партнерства Інститутом державно-політичних досліджень (IPRP), робочої групи, заснованої Урядом Північної Ірландії [10], а також таких авторів, як І. Борщ [7], Ю. Вдовенко [8], С. Петрик [5], можна виділити універсальні елементи:

1. Цілі державно-приватного партнерства - виконання завдань державного сектору, отримання запланованого результату по виробництву продукції або наданню соціально значущих послуг;

2. Кількість учасників державноприватного партнерства - державні та 
підприємницькі структури, фінансово-кредитні організації;

3. Відносини учасників - середньо- або довгострокові, закріплені офіційними документами;

4. Основа державно-приватного партнерства - інвестиційне проектування та спільна реалізація сучасних інвестиційних проектів публічними та приватними партнерами;

5. Поділ компетенцій, ризиків, доходів і витрат між сторонами державно-приватного партнерства.

На думку автора, для сфери охорони здоров'я слід до поняття «державноприватного партнерства», різних дослідників, додати доповнення та надати удосконалене визначення державно-приватного партнерства у наступному вигляді: державно-приватне партнерство - це співробітництво приватного сектору (підприємницьких структур) та публічного (державного) сектору, завдяки якому здійснюються завдання державного сектору в сфері економіки 3 поділом доходів, витрат, ризиків, зобов'язань, компетенції, в основою якого має бути інвестиційне проектування та спільна реалізація інвестиційних проектів публічними та приватними партнерами у сфері охорони здоров'я.
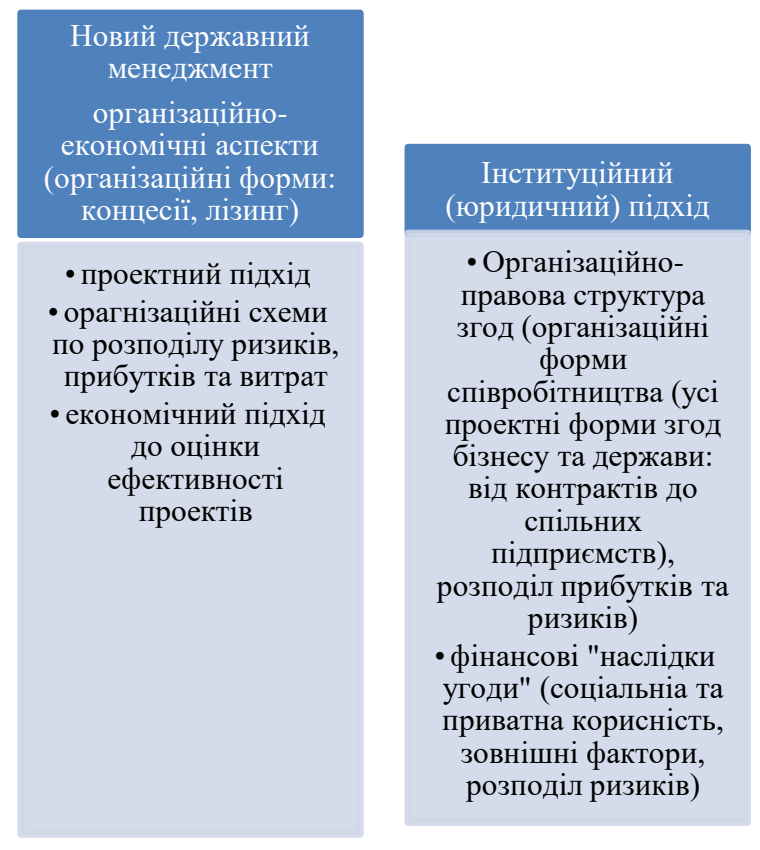

Різноманіття існуючих форм суспільно значущих проектів, що реалізуються на основі взаємодії влади і бізнесу, потребує чіткого визначення і класифікації, тому серед усього різноманіття зарубіжних i вітчизняних визначень можна виділити основні підходи до поняття державно-приватного партнерства як [11]:

- особливий тип управління «новий державний менеджмент» (New Public Management) або спосіб державної організації - організації «ефективного державного управління» (Good Governance);

- встановлена форма угод, що укладаються між бізнесом i владою щодо фінансових відносин і засобів (інституційний, юридичний підхід);

- стратегія або інструмент розвитку i модернізації економіки, гра слів, що використовується у політичних цілях для приховування за поняттям державноприватного партнерства різних, вже раніше існуючих, форм взаємодії з бізнесом, де термін державно-приватне партнерство покликаний надати їм вигляду нових інструментів розвитку.

Сукупність ознак державно-приватного партнерство, що висвітлюються в рамках того чи іншого підходу, можна звести до чотирьох основних підходів (рис. 1).
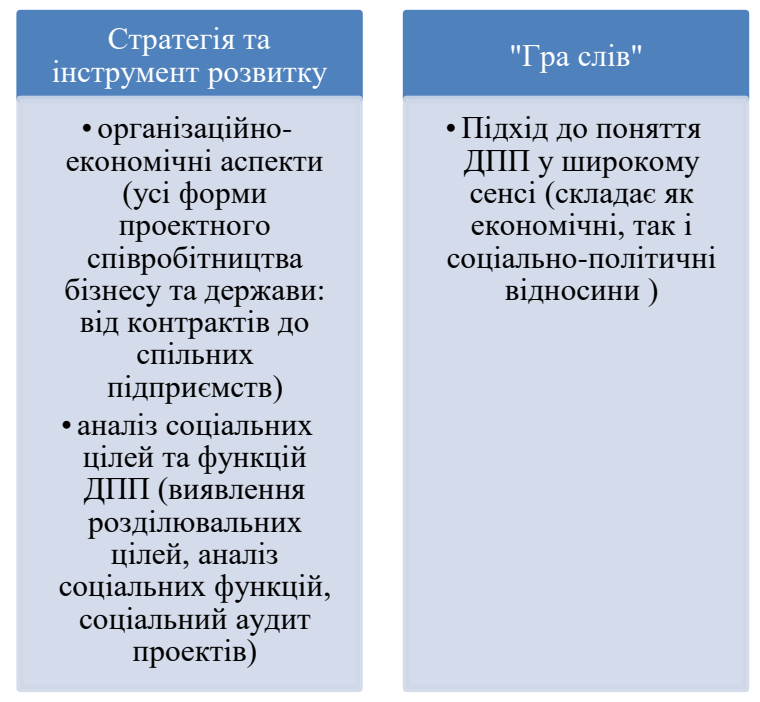

Рис. 1. Характеристика підходів до поняття державно-приватного партнерства Сформовано автором на основі [11] 
Аналіз визначень, поданих зарубіжними i вітчизняними дослідниками, міжнародними фінансовими інститутами розвитку та іншими спеціалізованими організаціями, дозволив зробити висновки, що більшість 3 трактувань слід відносити не до одного (за основною ознакою), а до двох або трьох підходів.

Так, автори і авторські колективи 3 розвинених країн дотримуються в основному підходів до визначення державно-приватного партнерства, пов'язаних з використанням його як інструменту управління $\mathrm{i}$ «мовної гри» (Швеція, Нідерланди, Австралія та ін.), деякі 3 авторів відзначають і фінансовий аспект (США, Австралія, Італія та ін.). Інституційний підхід максимально розкритий у визначеннях міжнародних фінансових інститутів та інститутів розвитку (Свропа, США та ін.). Щодо визначень українських, російських, білоруських авторів, слід відмітити, що в них чітко простежується прихильність до підходу, пов'язаному з розвитком [12]. Так, вітчизняний економіст В. Варнавський визначає державноприватне партнерство «як інституційний i організаційний альянс між державою i бізнесом 3 метою реалізації суспільно значущих проектів i програм у широкому спектрі галузей промисловості і НДДКР» [13]. Більшість інших вітчизняних авторів солідарні iз згаданим науковцем та доповнюють, модифікують i вдосконалюють його визначення, але сукупність підходів, в рамках яких воно існує, залишається незмінною [14].

В умовах сьогодення країни, які прагнуть досягнення ринкових характеристик сталого розвитку, до яких належить і Україна, покладають на державно-приватне партнерство додаткові функції, пов'язані 3 розвитком соціально-економічної сфери. Такий підхід, пов'язаний 3 використанням державно-приватного партнерства як інструменту розвитку, умовно можна позначити як «просторий», найбільш перспективний у впровадженні для сфери охорони здоров'я України, функціями якого виступають [15]:

1.У стратегічному аспекті - соціальноекономічний, інноваційний, розвиток i модернізація, комплексний розвиток територій, реалізація суспільно значущих проектів;

2. В інституційному аспекті - створення умов для формування ринків медичних послуг та інститутів, визначення форм взаємодії держави, бізнесу та інше.

3. «Европейський» підхід розуміє під державно-приватним партнерством непряму приватизацію i контрактні відносини, інкримінує партнерству наступні функції:

- компенсація «провалів ринку»;

- оптимізація громадського сектору та фінансів державного бюджету;

- перерозподіл повноважень 3 виробництва суспільних благ від державних структур до приватних.

Економічний ефект для суспільства від партнерств держави i приватного сектора полягає в тому, що воно одержує якісніші суспільні блага і послуги при зменшенні витрат. Партнерства сприяють розвитку ринкових відносин, приватної ініціативи i приватного підприємництва. Розвиток партнерств являє собою переосмислення взаємовідносин держави і приватного сектора, нові види організації діяльності, нові механізми регулювання.

Партнерство бізнесу і влади дозволяє істотно збільшити шанси на успіх при реалізації крупних проектів. Об'єднання ресурсів і справедливий розподіл ризиків між сторонами партнерства дозволяють активно залучати інвестиції для реалізації суспільно і соціально значущих проектів, багато 3 яких навряд чи могло бути реалізованим без об'єднання зусиль приватного і державного секторів.

Перевагами запровадження складових системи державно-приватного партнерства у сфері охорони здоров'я $є$ такі:

1) підвищення ефективності управління об'єктами державної та комунальної власності; 2) покращення якості надання послуг закладами охорони здоров'я;

3) створення умов для використання прогресивних зразків НТП закладами охорони здоров'я, опанування новітніх технологій та широке запровадження інновацій;

4) зниження навантаження на державний бюджет та оптимізація бюджетних видатків на надання публічних послуг та утримання бюджетних установ.

Відповідно до обраного стратегічного підходу на ринку медичних послуг наведемо систематизуємо види державно-приватного партнерства на основі $[7,8,15]$ (рис. 2). 


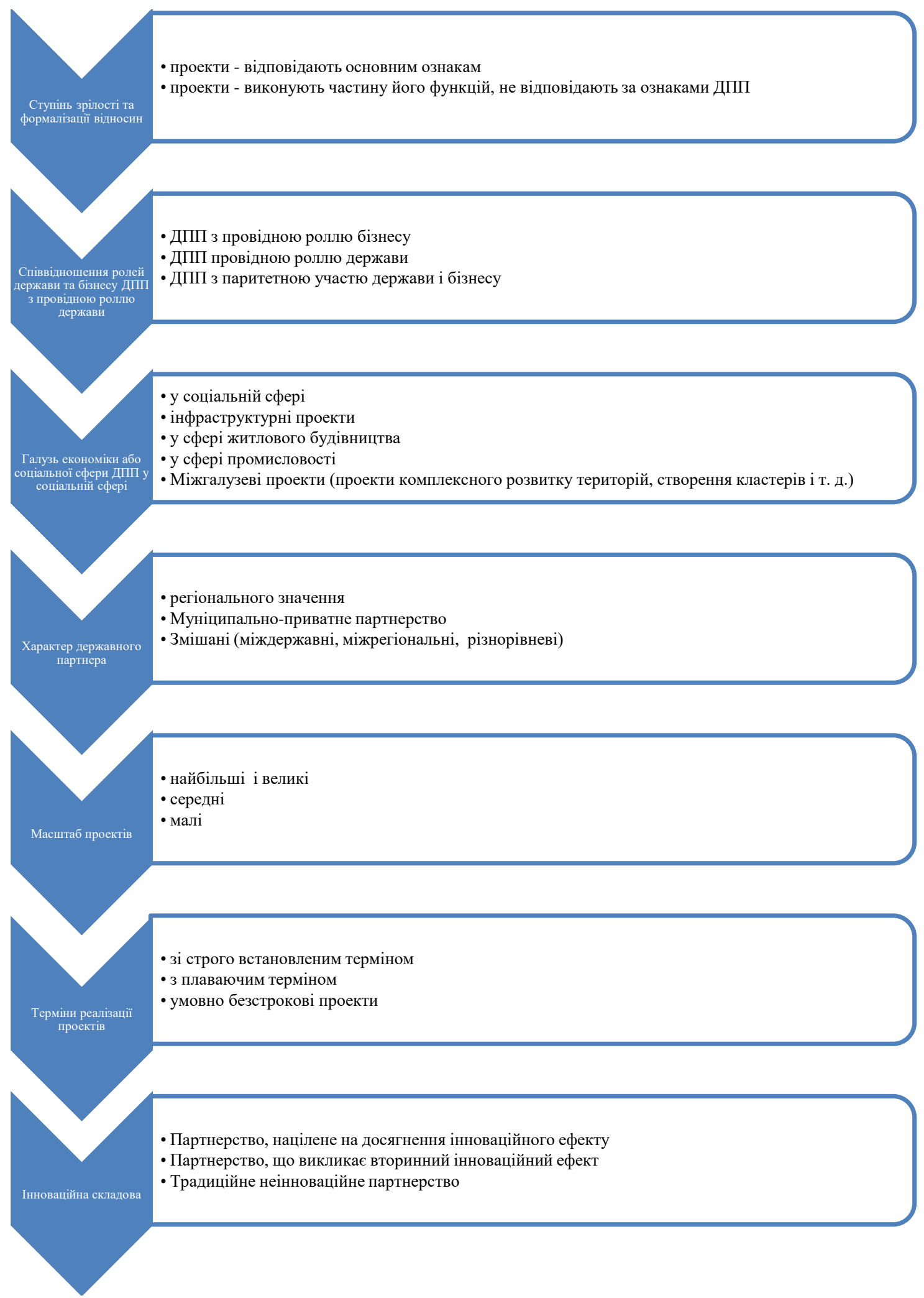

Рис. 2. Класифікація видів державно-приватного партнерства як інструменту сталого розвитку країни та іiі регіонів

Побудовано на основі [7, 8, 15]

Така класифікація набуває актуальності у вітчизняних реаліях, оскільки в рамках нового державного менеджменту має на меті вдосконалення державної політики в частині використання державно-приватного партнерства як інструменту розвитку сталих відносин в країні та іiі регіонах. Водночас, стратегічний підхід до державно-приватного 
партнерства вимагає класифікації видів державно-приватного партнерства, яка дозволяє об'єднувати в одному проекті певні сукупності різних видів досліджуваного інструменту, створюючи багато індивідуальних структур проектів для ефективного соціально-економічного розвитку держави та іiі регіонів. Іншими словами, потрібно інтегрувати застосовані в країні види проектів задля забезпечення сталого розвитку країни і їі регіонів.

Обговорення результатів. Таким чином, можна зазначити, що основними ознаками державно-приватного партнерства в медичній сфері, які розкривають специфіку партнерської взаємодії держави та приватного сектору як економічної категорії, є:

- наявність державного й приватного секторів;

- офіційні відносини між державними i приватними учасниками;

- взаємовідносини сторін носять партнерській, тобто рівноправний характер;

- довгострокові відносини між державою та приватним сектором;

- об'єднання активів (ресурсів i компетенцій) учасників;

- державна власність як об'єкт партнерства або спільна участь держави i бізнесу в господарській організації корпоративного типу;

- мета полягає в вирішенні державних завдань соціально-економічного розвитку країни / регіону в пріоритетних сферах економіки; розподілення ризиків між партнерами;

- перерозподіл відповідальності між сторонами партнерства для більш ефективної реалізації проекту;

- наявність доходного етапу в реалізації проекту державно-приватного партнерства.

Вище наведені характеристики виокремлюють державно-приватне партнерство серед інших форм економічної взаємодії держави і бізнесу (державними закупівлями, аутсорсингом та ін.).

Висновок. Отже, використання у науковій та практичній діяльності терміну державно-приватного партнерства пов'язано із впровадженням нової економічної форми взаємодії держави і приватного сектору для ефективного залучення та використання фінансових коштів i організаційних можливостей бізнесу в умовах обмеженості інвестиційних ресурсів держави.
Автором

було досліджено різноманітність форм i сфер застосування партнерської взаємодії держави і бізнесу, що робить ऑiі універсальним інструментом для вирішення державних завдань в пріоритетних сферах економіки та підвищення рівня конкурентоспроможності країни, забезпечення стійкого національного й регіонального зростання та формування сталих економічних відносин.

Перспективами

подальших

досліджень у даному напрямі є розроблення методичного забезпечення інструментарію регулювання та фінансування інституту державно-приватного партнерства у медичному секторі України.

\section{Список літератури}

1. Goldman M. Public-private partnerships needs honest brokering. Nature Med. 2012. № 18. P.341

2. Forgia G., Harding A. Public-Private Partnerships And Public Hospital Performance In São Paulo, Brazil. Health Affairs. 2009. Vol. 28, No. 4. doi.org/10.1377/hlthaff.28.4.1114

3. Clark R.M., Hakim S. Public-Private Partnerships and Their Use in Protecting Critical Infrastructure. Competitive Government: Public Private Partnerships. Springer, Cham, 2019. https://doi.org/10.1007/978-3-030-24600-6_1

4. Cheung E, Chan APC, Kajewski S. Reasons for implementing public private partnership projects: Perspective from Hong Kong, Australian and British practitioners. $J$ Property Investment Finance. 2009. P. 81-95.

5. Петрик С.M. Форми реалізації проєктів державно-приватного партнерства у сфері охорони здоров'я. Економіка, управління та адміністрування. 2020. № 2 (92). С. 88-94.

6. Дудка В. В. Переваги приватної медицини та вигоди держави у підтримці розвитку приватного сектора системи охорони здоров'я України (до проблеми державного регулювання здоровоохоронної сфери). Державне управління: удосконалення та розвиток. 2012. № 1. URL: http://www.dy.nayka.com.ua/?op=1\&z=381 (дата звернення: 17.11.2018).

7. Борщ B.I. Державно-приватне партнерство як запорука інноваційного розвитку національної галузі охорони здоров’я. Вісник ЖДТУ. 2019. № 2. С. 156-161.

8. Вдовенко Ю. С. Інструментарій приватно-державного партнерства в місцевому соціально-економічному розвитку. Теорія та 
практика державного управління: зб. наук. пр. ХарРІ НАДУ «Магістр», 2009. Вип. 3. С. 167172.

9. Петрова I. П. Система управління ризиками державно-приватного партнерства. Young Scientist. 2015. № 12 (27). C. 129-134.

10. Надолішній П. І., Піроженко Н. В. Публічно-приватне партнерство в Україні: теоретико-методологічні засади і умови інституціалізації. Теоретичні та прикладні питання державотворення. 2012. Вип. 10. - С. 17-52.

11. Костусенко А. И. Механизм взаимодействия властных и предпринимательских структур в рыночной среде. Проблемь современной экономики. 2008. № 2. С. 33-38.

12. Яшева Г.А. Теоретикометодологические основы и механизмы государственно-частного партнерства в инновационном развитии экономики Беларуси. Белорусский экономический журнал. 2011. № 3. C. 4-19.

13. Варнавский В. Новые подходы к финансированию инфраструктуры в Великобритании. Мировая экономика и международные отношения. 2012. № 9. С. 6774.

14. Запатріна I., Лебеда Т. Державноприватне партнерство як фактор економічного зростання та проблеми його розвитку в Україні. Економіст. 2011. № 3. С. 52-58.

15. Козаченко Ю. П. Впровадження механізму публічно-приватного партнерства 3 метою покращення інфраструктури регіону в умовах децентралізації управління. Право та державне управління. 2019. № 2 (35). Т. 1. C.197-202.

\section{References}

1. Goldman M. (2012). Public-private partnerships needs honest brokering. Nature Med., $18,341$.

2. Forgia G., Harding A. (2009). PublicPrivate Partnerships And Public Hospital Performance In São Paulo, Brazil. Health Affairs, 28, 4 [online]. Retrieved from: doi.org/10.1377/hlthaff.28.4.1114

3. Clark R.M., Hakim S. (2019). PublicPrivate Partnerships and Their Use in Protecting Critical Infrastructure. Competitive Government: Public Private Partnerships. Springer, Cham [online]. Retrieved from: https://doi.org/10.1007/978-3-030-24600-6_1
4. Cheung E, Chan APC, Kajewski S. (2009). Reasons for implementing public private partnership projects: Perspective from Hong Kong, Australian and British practitioners. J Property Investment Finance, 81-95.

5. Petrik S.M. (2019). Forms of implementation of public-private partnership projects in the field of health care. Economics, management and administration [Ekonomika, upravlinnya ta administruvannya], 2 (92), 88-94.

6. Dudka V.V. (2012). Advantages of private medicine and benefits of the state in supporting the development of the private sector of the health care system of Ukraine (to the problem of state regulation of the health care sector). Public administration: improvement and development [Derzhavne upravlinnya: udoskonalennya ta rozvytok], 1 [online]. Retrieved from: http://www.dy.nayka.com.ua/?op=1\&z=381

7. Borsch V.I. (2019). Public-private partnership as a guarantee of innovative development of the national healthcare sector. Bulletin of ZhSTU [Visnyk ZHDTU], 2, 156-161.

8. Vdovenko Yu. S. (2009). Tools of public-private partnership in local socio-economic development. Theory and practice of public administration: coll. Science. pr. HarRI NAPA "Master" [Teoriya ta praktyka derzhavnoho upravlinnya: zb. nauk. pr. KharRI NADU «Mahistr»], 3, 167-172.

9. Petrova I.P. (2015). Public-private partnership risk management system. Young Scientist, 12 (27), 129-134.

10. Nadolishniy P.I., Pirozhenko N.V. (2012). Public-private partnership in Ukraine: theoretical and methodological principles and conditions of institutionalization. Theoretical and applied issues of state formation [Teoretychni ta prykladni pytannya derzhavotvorennya], 10, 1752.

11. Kostusenko A.I. (2008). Mechanism of interaction between power and business structures in the market environment. Problems of the modern economy [Problemy sovremennoy ekonomiki], 2, 33-38.

12. Yasheva G.A. (2011). Theoretical and methodological foundations and mechanisms of public-private partnership in the innovative development of the Belarusian economy. Belarusian economic journal [Belorusskiy ekonomicheskiy zhurnal], 3, 4-19.

13. Varnavsky V. (2012). New approaches to financing infrastructure in the UK. World economy and international relations [Mirovaya 
ekonomika i mezhdunarodnyye otnosheniya], 9, 67-74.

14. Zapatrina I., Lebeda T. (2011). Publicprivate partnership as a factor of economic growth and problems of its development in Ukraine. Economist [Ekonomist], 3, 52-58.
15. Kozachenko Yu. P. (2019). Introduction of a mechanism of public-private partnership in order to improve the infrastructure of the region in the context of decentralization of management. Law and public administration [Pravo ta derzhavne upravlinnya], 2 (35), 1, 197-202.

Надійшла до редакиї̈ 28.10.2019p.

Байрак Анжела Олегівна - старший викладач кафедри публічного управління та адміністрування,

Донецький державний університет управління

E-mail: eurospinemadmin@ukr.net

\section{THEORETICAL AND METHODICAL APPROACHES FOR FORMING SUSTAINABLE RELATIONS IN PUBLIC-PRIVATE PARTNERSHIP IN THE MEDICAL INDUSTRY OF UKRAINE}

The article summarizes scientific discussions on the use of public-private partnership in the health sector and concludes that it is relevant as a tool for sustainable development of the country, regions and individual industries. The structural elements of public-private partnership have been identified. Based on the systematization of literary sources on approaches to the definition of public-private partnership, it was found that the content of the category "public-private partnership" is revealed through the complementarity of the project and institutional approaches, as well as in aspects of strategic development and stylistic reception in a broad sense, as a result of which the author's interpretation of the category public-private partnership in the medical field. The types of public-private partnerships as a tool for sustainable development of the country and its regions are systematized and the feasibility of integrating various projects is substantiated. The main features of public-private partnership in the medical field are revealed, revealing the specifics of partnership between the state and the private sector as an economic category. Key words: publicprivate partnership, private sector, medical sphere, healthcare, sustainable development. It is proved that the use of the term publicprivate partnership in scientific and practical activities is associated with the introduction of a new economic form of interaction between the state and the private sector for effective attraction and use of financial resources and organizational opportunities of business in limited investment resources. The author explored the variety of forms and areas of partnership between the state and business, which makes it a universal tool for solving government problems in priority areas of the economy and increasing the country's competitiveness, ensuring sustainable national and regional growth and sustainable economic relations.

Key words: public-private partnership, private sector, medical sphere, healthcare, sustainable development.

Bairak Anzhela - Senior Lecturer at the Department of Public Administration and Administration

Donetsk state university of management

E-mail: eurospinemadmin@ukr.net

\section{ТЕОРЕТИКО-МЕТОДИЧЕСКИЕ ПОДХОДЫ ФОРМИРОВАННИЯ УСТОЙЧИВЫХ ОТНОШЕНИЙ ГОСУДАРСТВЕННО-ЧАСТНОГО ПАРТНЕРСТВА В МЕДИЦИНСКОЙ ОТРАСЛИ УКРАИНЫ}

В статье обобщены научные дискуссии по применению государственно-частного партнерства в сфере здравоохранения и сделан вывод о его актуальности как инструмента устойчивого развития странь, регионов и отдельных отраслей. Определены структурные элементы государственно-частного партнерства. На основе систематизации литературных источников по подходам к определению государственно-частного партнерства выяснено, что содержание категории «государственно-частное партнерство» раскрывается через взаимодополнения проектного и институичонального подходов, а также в аспектах стратегического развития и стилистического приема в иироком смысле, в результате чего предоставлено авторское толкование категории государственно-частное партнерство в медицинской сфере. Систематизированы виды государственно-частного партнерства как инструмента устойчивого развития страны и ее регионов и обоснована иелесообразность интеграции различных проектов. Выявлены основные признаки государственно-частного партнерства в медицинской сфере, раскрываюших специфику партнерского взаимодействия государства и частного сектора как экономической категории.

Ключевые слова: государственно-частное партнерство, частный сектор, медицинская сфера, здравоохранение, устойчивое развитие.

Байрак Анжела Олеговна - старший преподаватель кафедры публичного управления и администрирования, Донецкий государственный университет управления

E-mail: eurospinemadmin@ukr.net 